\title{
IMPLEMENTASI IDENTIFIKASI PASIEN OLEH PERAWAT DI SALAH SATU RUMAH SAKIT DI INDONESIA MASIH BELUM OPTIMAL
}

\author{
Wiwin Nur Aeni \\ (STIKes Indramayu, Program Studi Profesi Ners, Email: \\ wiwinnuraeni505@gmail.com) \\ Alvian Pristy Windiramadhan \\ (STIKes Indramayu, Program Studi Sarjana Keperawatan, Email: \\ mr.ianramadhan@gmail.com) \\ Amalia Rizqi Sholihah \\ (STIKes Indramayu,Program Studi Sarjana Keperawatan. Email: \\ amaliarizqisholihah2908@gmail.com)
}

\begin{abstract}
ABSTRAK
Angka kejadian salah identifikasi pasien di dunia dikategorikan tinggi dengan angka $13 \%$ pada kasus bedah dan $67 \%$ pada pemberian tranfusi darah. Pada tahun 2009 s.d. 2011, sebanyak 65,5\% terjadi salah identitas dan kesalahan laboratorium di salah satu rumah sakit di Indonesia. Kesalahan tersebut dominan terjadi di ruang rawat inap dengan angka 60\%. Penelitian ini bertujuan mengetahui gambaran pelaksanaan identifikasi pasien di salah satu rumah sakit yang sudah terakreditasi. Penelitian menggunakan desain survey deskriptif. Populasi penelitian yakni perawat ruang rawat inap di salah satu rumah sakit di Kabupaten Indramayu yang telah terakreditasi. Sampel berjumlah 113 responden dengan menggunakan proportional sampling dari seluruh ruang rawat inap. Instrumen menggunakan koesioner dengan 20 pernyataan skala likert (uji validitas $\mathrm{r}$ tabel 0,374 , uji reliabilitas 0,611). Analisa data dalam bentuk distribusi frekuensi dan prosentase. Hasil menunjukkan pelaksanaan identifikasi pasien kurang sebanyak $46,9 \%$, penggunaan gelang identitas kurang sebanyak 45,1\%, pengecekan identitas pasien kurang sebanyak $46,9 \%$, dan identifikasi pasien tidak sadar kurang sebanyak $72,6 \%$. Disarankan rumah sakit mengoptimalkan monitoring dan evaluasi pelaksanaan identifikasi pasien, supervisi, dan penetapan reward serta pembinaan.
\end{abstract}

Kata Kunci : Implementasi, Identifikasi Pasien

\begin{abstract}
The number of misidentification of patients in the world is still high, with $13 \%$ in surgical cases and 67\% in administration of blood transfusions. In 2009 until 2011, number of mistaken identities and laboratory errors reach $65.5 \%$ in Indonesia. The incident are happen dominantly in the inpatient ward as much as $60 \%$. The purpose of the study is to describe the implementation of patient identification in the accredited hospital. The research used descriptive survey design. The population was inpatient nurses in the accredited hospital in Indramayu Regency. The sample was taken by proportional sampling as much as 113 respondents. The instrument was questionnaires with 20 Likert scale
\end{abstract}


statements (test validity $r$ table 0.374 , reliability test 0.611 ). Data was analyzed in frequency distribution and percentage form. The results showed that $46.9 \%$ identification of patients was less, $45.1 \%$ using identity bracelets was less, $46.9 \%$ checking identity of patients was less, and $72.6 \%$ identification of unconscious patients was less. We suggest manager hospital to optimize monitoring and evaluation the implementation of patient identification, supervision, giving rewards and guidance.

Keyword: Implementation, Patient Identification

\section{PENDAHULUAN}

Pasien yang datang untuk mendapatkan pelayanan rumah sakit berjumlah besar dengan beragam masalah disertai pemeriksaan, diagnosa, perawatan, dan pengobatan yang berbeda. Pasien berpeluang besar untuk memiliki nama yang sama, wajah yang hampir serupa, dan alamat yang hampir sama. Kondisi ini memiliki risiko terjadinya kesalahan pasien dalam pemberian perawatan (KARS, 2017).

Perawat sebagai petugas kesehatan yang paling banyak bertugas di rumah sakit. Perawat dituntut untuk mampu mengidentifikasi pasien dengan benar dan tepat agar dapat memberikan pelayanan prima di rumah sakit dengan tepat sesuai kaidah keselamatan pasien (Hughes, 2008).

World Health Assosiation (WHO) menyampaikan bahwa terdapat beberapa Negara yang mendapatkan dampak negatif bagi pasien selama mendapatkan perawatan di fasilitas pelayanan kesehatan. Di Negara yang telah maju, 1 dari 10 pasien mendapatkan injuri ketika dirawat di rumah sakit. Di 26 Negara berkembang dan Negara tertinggal, terdapat $8 \%$ risiko kejadian injuri dengan angka kematian mencapai 30\%. Kesalahan dalam pemberian obat menjadi salah satu penyebab kerugian finansial mencapai $\$ 42.000 .000$ per tahun (WHO, 2018). Masalah-masalah tersebut seharusnya dapat dicegah dengan menegakkan identifikasi pasien yang baik. Namun, data menunjukkan bahwa salah identifikasi pasien di dunia masih tinggi pada kasus bedah dengan angka $13 \%$ dan pemberian tranfusi darah 67\%. Hal tersebut menyebabkan meninggalnya 11 orang pasien (The Joint Commission, 2012). Data dari laporan insiden keselamatan pasien di Indonesia menyebutkan bahwa telah terjadi salah identitas dan kesalahan laboratorium sebanyak $65,5 \%$ dari total kasus sebanyak 171 insiden pada tahun 2009 sampai dengan 2011. Sebanyak 60\% insiden keselamatan pasien dominan terjadi di ruang inap (Mulyana, 2013). Insiden akibat kesalahan pelayanan medis tercatat $1: 25$ dengan kerugian mencapai $1: 10$ dan kematian 44000 sampai dengan 98000 pasien per tahun. Pasien dan keluarga pun akan mengalami kerugian dari segi pembiayaan yang meningkat dari yang seharusnya pasien keluarkan (Belinda, 2016).

Studi pendahuluan yang dilakukan di rumah sakit terakreditasi menyatakan bahwa terjadi kesalahan pemberian 
transfuse darah yang menyebabkan kematian pasien. Hasil wawancara terhadap Kepala Ruangan menjelaskan bahwa kesalahan pemberian transfuse darah dikarenakan kurangnya ketelitian dalam memastikan identitas pasien. Kondisi ini bertentangan dengan pernyataan Joint Commission Internasional (JCI) yang mengatur keselamatan pasien. Ketepatan identifikasi pasien harus dipastikan sebelum pasien tersebut mendapatkan pemeriksaan, pengobatan, maupun tindakan pelayanan lainnya. International Patient Safety Goals (IPSG) mensyaratkan keakurasian identifikasi pasien dalam penyelenggaraan pelayanan berbasis kesehatan di Rumah Sakit.

Kemungkinan salah pasien dapat terjadi ketika pasien dalam keadaan tersedasi, disorientasi, penurunan kesadaran, pindah tempat tidur, pindah kamar, tidak ingat pada identitas pribadinya, dan kondisi lainnya yang mengarah pada kesalahan identifikasi pasien. Kemungkinan - kemungkinan tersebut dapat diantisipasi dengan prosedur identifikasi pasien minimal melalui dua data yang diantaranya adalah nama pasien, tanggal lahir, nomor rekam medis, nomor induk kependudukan, atau kode batang (KARS,2017).

Kesalahan identifikasi dapat memberikan dampak negatif baik bebagai pihak. Kerugian tersebut dapat dialami oleh pasien, petugas kesehatan, termasuk bagi rumah sakit itu sendiri (Muslim, 2009). Pasien yang tidak tepat identifikasi dapat berpeluang untuk mendapatkan kesalahan pengobatan yang tentunya merugikan kesehatan pasien bahkan berakibat pada kematian.

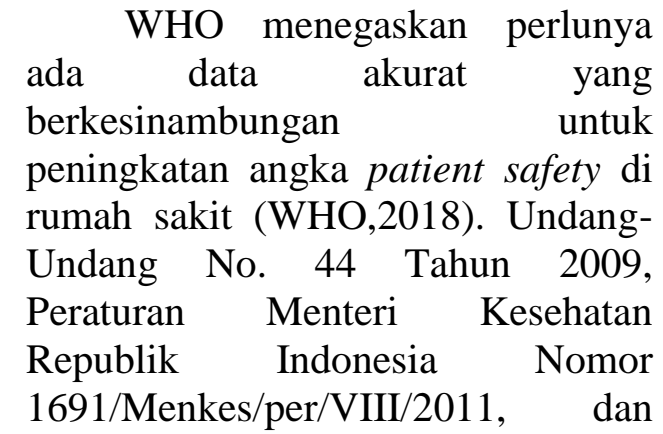
Standar Nasional Akreditasi Rumah Sakit menekankan pencapaian ketepatan identifikasi pasien. Bahkan Undang - Undang Nomor 38 Tahun 2014 tentang Keperawatan mengatur sangsi yang diberikan kepada perawat ketika melakukan kesalahan. Seorang perawat yang tidak mampu melakukan identifkasi pasien dengan tepat tentunya akan mendapatkan sangsi. Sangsi tersebut ketika tidak menimbulkan dampak maka akan mendapat teguran. Namun apabila kelalaian perawat tersebut menimbulkan kerugian bagi pasien maka akan mendapatkan peringatan bahkan pada pencabutan izin.

Efek bagi rumah sakit dirasakan pada penurunan citra rumah sakit. RS tidak mampu untuk memberikan pelayanan yang aman sesuai standar. Masyarakat sebagai pengguna layanan kesehatan mengalami ketidakpuasan. Hal ini dibuktikan melalui penelitian yang menunjukan bahwa pelaksanan identifikasi pasien dengan tepat berhubungan dengan kepuasan dari pasien (Umaternate, 2015).

Berdasarkan fenomena tersebut, peneliti tertarik melakukan penelitian dengan topik "Bagaimanakah Pelaksanaan Identifikasi Pasien di Ruang Rawat Inap rumah sakit di Indonesia?" Tujuan penelitian ialah untuk mengetahui gambaran penggunaan gelang identitas, pengecekan 
identitas pasien, dan identifikasi pasien tidak sadar.

\section{METODE PENELITIAN}

Penelitian menggunakan desain survey deskriptif untuk melihat gambaran implementasi identifikasi pasien oleh perawat di 11 ruang rawat inap salah satu rumah sakit terakreditasi di Indonesia (Notoatmodjo, 2010). Penelitian ini mendeskripsikan akumulasi data dasar pelaksanaan identifikasi pasien secara rinci meliputi penggunaan gelang identitas, pengecekan identitas pasien, dan identifikasi pasien tidak sadar (Badriah, 2012). Populasi yakni perawat ruang inap di salah satu rumah sakit terakreditasi di Kabupaten Indramayu sebanyak 173 orang (Dharma, 2011). Sampel penelitian sebanyak 113 responden (rumus Sloven, $\alpha=10 \%$ ). Besarnya sampel yang diambil dari setiap ruang rawat inap menggunakan rumus proportional sampling. Kriteria inklusi yakni perawat yang ada di ruang inap salah satu rumah sakit terakreditasi di Kabupaten Indramayu pada saat penelitian berlangsung dengan minimal pendidikan D3 keperawatan dan bersedia menjadi responden. Kriteria eksklusi yakni perawat yang masih menjalani cuti, sakit, atau menjalani tugas belajar pada saat penelitian berlangsung (Notoatmodjo, 2010). Penelitian telah dilaksanakan di bulan September 2018. Peneliti menerapkan etika penelitian yang meliputi Right to anonymity and confidentiality, self determination, privacy and dignity, fair treatment, protection from discomfort and harm (Nursalam, 2013).

Alat pengumpul data pada penelitian ini menggunakan kuesioner (Arikunto, 2010). Lembar kuesioner yang diberikan berbentuk pernyataan dimana pilihan jawaban telah tersedia (closed endeed item / structured). Instrumen pelaksanaan identifikasi disusun mengacu pada Standar Nasional Akreditasi Rumah Sakit. Uji coba instrumentasi telah dilakukan dengan menggunakan uji validitas dan reliabilitas di rumah sakit terakreditasi yang berbeda dengan tempat penelitian. Instrument diujivaliditaskan kepada 30 perawat ( $\mathrm{r}$ tabel 0,374, uji reliabilitas 0,611, $\alpha=5 \%$ ) (Arikunto, 2010). Instrumen terdiri dari 20 pernyataan dengan pilihan jawaban skala likert (selalu, sering, kadang, tidak pernah). Instrument untuk penggunaan gelang identitas terdiri dari 8 pernyataan dengan 5 pernyataan favorable dan 3 unfavorable. Instrument pengecekan identitas pasien terdiri dari 8 pernyataan dengan 6 favorable dan 2 unfavorable. Instrumen identifikasi pasien tidak sadar terdiri dari 4 pernyataan dangan 3 favorable dan 1 unfavorable.

Pada saat penelitian, responden diminta mengisi koesioner dengan jujur. Metode analisa data menggunakan analisis univariat distibusi frekuensi dan prosentase.

\section{HASIL PENELITIAN}

\section{Karakteristik Responden}

Karakteristik yang disajikan pada penelitian ini data demografi responden berisi umur, pendidikan terakhir, jenis kelamin, lama kerja, serta pengalaman mengikuti pelatihan keselamatan pasien. Berikut tabel distribusi frekuensi responden berdasarkan umur, pendidikan terakhir, jenis kelamin, lama kerja, serta pengalaman mengikuti pelatihan: 
Tabel 1.

Karakteristik Responden Perawat Rumah Sakit di Kabupaten Indramayu Tahun 2018

\begin{tabular}{|c|c|c|}
\hline Umur & Jumlah & Persentase (\%) \\
\hline $\begin{array}{c}\text { Dewasa awal (21 s.d. 40 } \\
\text { tahun) }\end{array}$ & 92 & 81,4 \\
Dewasa tengah (41 s.d. & 21 & 18,6 \\
59 tahun) & Jumlah & Persentase (\%) \\
Jenis Kelamin & 30 & 26,5 \\
Laki - Laki & 83 & 73,5 \\
Perempuan & Jumlah & Persentase (\%) \\
\hline Pendidikan Terakhir & 57 & 50,4 \\
\hline D3 Keperawatan & 56 & 49,6 \\
\hline Ners & Jumlah & Persentase (\%) \\
\hline Lama Kerja & 46 & 50,7 \\
\hline Baru (<6 tahun) & 67 & Persentase (\%) \\
\hline Lama ( $\geq 6$ tahun) & Jumlah & 69,9 \\
\hline Pengalaman Pelatihan & 79 & 30,1 \\
\hline Ya & 34 & 100 \\
\hline Tidak & 113 & \\
\hline Jumlah & &
\end{tabular}

Berdasarkan tabel 1 , responden dewasa awal sebanyak 92 responden $(81,4 \%)$, jenis kelamin perempuan sebanyak 83 responden $(73,5 \%)$, pendidikan D3 Keperawatan sebanyak 57 responden $(50,4 \%)$, kerja kategori lama sebanyak 6 responden $(59,3 \%)$, dan telah mengikuti pelatihan keselamatan pasien sebanyak 79 responden $(69,9 \%)$.

\section{Pelaksanaan Identifikasi Pasien} $46,9 \%$ pelaksanaan identifikasi pasien kurang, $45,1 \%$ penggunaan gelang identitas kurang, 46,9\% pengecekan identitas pasien kurang, dan $72,6 \%$ identifikasi pasien tidak sadar kurang. Hasil tersebut secara jelas digambarkan melalui tabel 2 berikut ini :

Tabel 2.

Pelaksanaan Identifikasi Pasien, Penggunaan Gelang Identitas, Pengecekan Identitas Pasien, dan Identifikasi Pasien Tidak Sadar

\begin{tabular}{|c|c|c|}
\hline $\begin{array}{c}\text { Pelaksanaan Identifikasi } \\
\text { Pasien }\end{array}$ & Jumlah & Persentase (\%) \\
\hline Kurang & 53 & 46,9 \\
Baik & 60 & 53,1 \\
\hline $\begin{array}{c}\text { Penggunaan Gelang } \\
\text { Identitas }\end{array}$ & Jumlah & Persentase (\%) \\
\hline Kurang & 51 & 45,1 \\
\hline Baik & 62 & 54,9 \\
\hline
\end{tabular}




\begin{tabular}{|c|c|c|}
\hline $\begin{array}{c}\text { Pengecekan Identitas } \\
\text { Pasien }\end{array}$ & Jumlah & Persentase (\%) \\
\hline Kurang & 53 & 46,9 \\
\hline Baik & 60 & 53,1 \\
\hline $\begin{array}{c}\text { Identifikasi Pasien Tidak } \\
\text { Sadar }\end{array}$ & Jumlah & Persentase (\%) \\
\hline Kurang & 82 & 72,6 \\
\hline Baik & 31 & 27,4 \\
\hline Jumlah & 113 & 100 \\
\hline
\end{tabular}

\section{PEMBAHASAN}

Pelaksanaan identifikasi pasien, penggunaan gelang identitas, pengecekan identitas pasien, dan identifikasi pasien tidak sadar, masing-masing adalah 46,9\%, $45,1 \%$, 46,9\&, dan 72,6\% masih kurang dalam pelaksanaannya. Hasil ini lebih rendah dari target WHO dan standar akreditasi nasional bahwa pelaksanaan identifikasi pasien, penggunaan gelang identitas, pengecekan identitas pasien, dan identifikasi pasien tidak sadar seharusnya terlaksana dengan baik.

Keadaan ini sejalan dengan penelitian Lestari dan Aini (2012) yang menyebutkan bahwa pelaksanaan identifikasi di rumah sakit di Yogyakarta belum sesuai standar. Temuan bahwa pasien di ruang rawat inap belum menggunakan gelang identitas, belum terlaksana penyampaian edukasi manfaat penggunaan gelang identitas, dan belum terealisasi identifikasi sesuai prosedur. Meskipun di rumah sakit tersebut telah melaksanakan upaya ronde patient safety, memastikan kelengkapan dokumen penunjang, mensosialisasikan prosedur, dan memasang poster identifikasi pasien.

Penggunaan gelang identitas oleh perawat kepada pasien masih kurang baik karena setelah pemasangan gelang identitas, perawat tidak menjelaskan manfaat penggunaan gelang tersebut. Perawat yang menjelaskan manfaat penggunaan gelang baru mencapai $35,18 \%$. Selain itu, perawat tidak melaksanakan pemeriksaan gelang pasien setelah melakukan tindakan kepada pasien. Perawat yang melakukan pemeriksaan gelang pasien setelah tindakan baru mencapai 39,60\%.

Pengecekan identitas pasien oleh perawat masih kurang baik karena perawat lebih sering memberikan pertanyaan tertutup kepada pasien, misalnya "Apakah benar dengan Saudara/I X?". Perawat yang memberikan pertanyaan terbuka baru mencapai 43,36\%.

Identifikasi pasien tidak sadar masih kurang baik karena perawat hanya melihat gelang identitas pasien pada pasien yang mengalami penurunan kesadaran, tanpa mengkonfirmasi identitas pasien kepada keluarga. Perawat yang mengkonfirmasi identitas pasien kepada keluarga baru mencapai 47,34\%.

Masih kurang baiknya pelaksanaan identifikasi pasien dimungkinkan karena faktor budaya. Yudhawati dan Listiowati (2007) menyebutkan bahwa monitor dan 
evaluasi pelaksanaan identifikasi pasien berkesinambungan di Rumah Sakit oleh pihak managerial, akan menciptakan budaya bagi petugas dalam identifikasi pasien. Sehingga disarankan kepada rumah sakit, agar dapat menjalankan monitoring dan evaluasi berkelanjutan yang rutin sehingga budaya keselamatan pasien dapat ditegakkan. Selain itu, supervisi dimungkinkan dapat meningkatkan pelaksanaan identifikasi pasien. Aeni dkk (2016) menyebutkan bahwa dalam supervisi, permasalahan yang ditemui akan diklarifikasi dengan jelas dan mendapatkan umpan balik. Proses klarifikasi dan umpan balik ini yang menjadi salah satu penguat dalam supervisi yang selama ini telah banyak dilaksanakan di rumah sakit.

Penggunaan gelang identitas pasien yang sudah baik adalah ketika perawat mengecek penggunaan gelang identitas sesuai dengan jenis kelaminnya $(97,12 \%)$, mensinkronkan gelang identitas sesuai identitas pasien $(97,12 \%)$, dan memasang tanda risiko sesuai kondisi pasien $(93,36 \%)$.

Pengecekan identitas pasien yang sudah baik adalah ketika perawat mencocokkan nama pasien dan nomor registrasi pasien atau tanggal lahir sebelum pemberian obat atau produk darah, pengambilan darah, pemeriksaan penunjang, dan tindakan invasive $(96,90 \%)$. Pengecekan identitas pasien tidak sadar yang sudah baik dilaksanakan adalah ketika perawat memastikan nama pasien yang mengalami penurunan kesadaran kepada keluarga sebelum melakukan tindakan atau perawatan $(96,02) \%$.

\section{SIMPULAN}

$46,9 \%$ pelaksanaan identifikasi pasien kategori kurang, 45,1\% penggunaan gelang identitas kategori kurang, 46,9\% pengecekan identitas pasien kategori kurang, dan $72,6 \%$ identifikasi pasien tidak sadar kategori kurang.

\section{SARAN}

Manager rumah sakit mengoptimalkan monitoring, evaluasi, supervisi, penerapan reward dan pembinaan.

\section{DAFTAR PUSTAKA}

Aeni, W.N., Hartiti, T., dan Warsito, B.E. 2016. Faktor Pendukung dan Penghambat Pelaksanaan Supervisi Untuk Meningkatkan Kepatuhan Perawat Dalam Menerapkan SPO Pemasangan Infus Di RSUD Indramayu. Universitas Diponegoro; 2016.

Badriah, D.Laelatul. 2012. Metodologi Penelitian IlmuIlmu Kesehatan. Bandung : Multazam

Belinda, M. 2016. Pelaporan Insiden Keselamatan Pasien. RSUD Dr Saiful Anwar Malang

Departemen Kesehatan RI. 2011. Peraturan Menteri Kesehatan Republik Indonesia. Nomor 1691/MENKES/PER/VIII/20

11 Tentang Keselamatan Pasien Rumah Sakit

Dharma, K.Kelana. 2011. Metodologi Penelitian Keperawatan (Pedoman Melaksanakan dan Menerapkan Hasil 
Penelitian). Jakarta : Trans Info Media

Hamzah, A. 2008. Hukum Acara Pidana Indonesia. Jakarta:Sinar Grafika

Hidayat, A. Alimul. 2007. Metode Penelitian dan Teknik Analisis Data.Jakarta: Salemba Medika.

Hughes R.G . 2008. Patient safety and quality : An evidencebased handbook for nurses. (Prepared with support from the Robert Wood Johnson Foundation).

AHRQ Publication No. 08-0043. Rockville, MD: Agency for Healthcare Research and Quality

Joint Commission Acreditation. 2015. Hospital National Patient Safety Goals. Diakses 27 Agustus 2017 http://www.jointcommission. org/

Joint Commission International. 2013. Joint Commission International Acredditation Standards for Hospital.

Komisi Akreditasi Rumah Sakit. 2012. Instrumen Akreditasi Rumah Sakit Standar Akreditasi 2012 Edisi 1

Komisi Akreditasi Rumah Sakit. 2017. Standar Nasional Akreditasi Rumah Sakit.

Martin Doll Associates. 2008. Australian commission on safety and quality in health care. Technology Solutions to Patient Misidentification. Report of review, final. Diakses 30 Agustus 2017. http://www.safetyandquality. gov.au/

Mulyana, D.Sri, 2013.Analisis Penyebab Insiden Keselamatan Pasien Oleh Perawat di Unit Rawat Inap RS X Jakarta. Tesis UI Depok

Muslim, M. Fauzan. 2009. FaktorFaktor Yang Mempengaruhi Perawat Dalam Pelaksanaan Identifikasi Pasien Di Rumah Sakit Puri Indah Jakarta Barat. Tesis. Universitas Esa Unggul

Notoatmodjo, S. 2010. Metodologi Penelitian Kesehatan. Jakarta : Rineka Cipta

Nursalam. 2013. Konsep Penerapan Metode Penelitian Ilmu Keperawatan. Jakarta: Salemba Medika.

Sunaryo.2009.Malpraktik dalam Keperawatan. Jakarta:EGC

The Joint Commission. 2012. Meeting The Joint Commission's National Patient Safety Goals. Joint Commission Resources, Inc. USA

Umaternate, T.Sari, Kumaat, L.T, dan Mulyadi. 2015. Hubungan Pelaksanaan Identifikasi Pasien Secara Benar Dengan Kepuasan Pasien Di Instalasi Gawat Dadurat (IGD) RSUP Prof. Dr. R. D. Kandou Manado. eJournal Keperawatan (eKp) Volume 3 Nomor 2

Undang-Undang No. 38 Tahun 2014

Undang-Undang No. 44 Tahun 2009 
WHO. Patient Safety. Yudhawati, D.D dan Listiowati, E. ww.who.int/patientsafety/en/ 2007. The Evaluation of Implementation for

Lestari, S dan Aini, Q. 2012. Identification of Patient in Pelaksanaan Identifikasi Pasien Berdasarkan Standar Akreditasi JCI Guna Meningkatkan Program Patient Safety Di RS PKU Muhammadiyah Yogyakarta Staying Room at Siti Aisyah Madiun Islamic Hospital. Journal of Experimental Psychology: General Vol 136 Page 23-42.

Unit II 